\title{
Congenital self-healing reticulohistiocytosis in a newborn: unusual oral and cutaneous manifestations
}

\author{
Alessandra Rizzoli ${ }^{1}$, Simona Giancristoforo ${ }^{2 *}$ (D) Cristina Haass ${ }^{1}$, Rita De Vito ${ }^{3}$, Stefania Gaspari ${ }^{4}$, Eleonora Scapillati ${ }^{1}$, \\ Andrea Diociaiuti $^{2}$ and May El Hachem ${ }^{2}$
}

\begin{abstract}
Background: Congenital self-healing reticulohistiocytosis (CSHRH), also called Hashimoto-Pritzker disease, is a rare and benign variant of Langerhans cell histiocytosis, characterized by cutaneous lesions without extracutaneous involvement.

Case presentation: We present a case of CSHRH with diffuse skin lesions and erosions in the oral mucosa, present since birth and lasting for 2 months, and we perform a review of the literature on Pubmed in the last 10 years.

Conclusions: Our case confirm that lesions on oral mucosa, actually underestimated, may be present in patients with CSHRH. Patients affected by CSHRH require a close follow-up until the first years of life, due to the unpredictable course of Langerhans cell histiocytosis, in order to avoid missing diagnosis of more aggressive types of this disorder.
\end{abstract}

Keywords: Congenital self-healing reticulohistiocytosis, CSHRH, Hashimoto-Pritzker disease, Histiocytosis, Newborn

\section{Background}

Congenital self-healing reticulohistiocytosis (CSHRH), also known as Hashimoto-Pritzker disease, is a rare benign type of Langerhans cell histiocytosis (LCH) described in 1973 [1, 2].

CSHRH manifests generally at birth or during the neonatal period with multiple red-brown papules, nodules, or vesicles and spontaneous regression within a few months. Solitary lesions are also reported [3]. In addition, it is characterized by lack of systemic involvement. Nevertheless, long-term follow-up is recommended due to the unpredictable course of Langerhans cell histiocytosis [4-6].

\footnotetext{
* Correspondence: simona.giancristoforo@opbg.net

${ }^{2}$ Dermatology Unit, Bambino Gesù Children's Hospital, IRCCS, Piazza S. Onofrio, 4, 00165 Rome, Italy

Full list of author information is available at the end of the article
}

We report a case of a newborn with cutaneous and oral mucosa involvement. In addition, a review of the literature was perfomed on Pubmed using the following mesh terms: "Congenital self-healing reticulohistiocytosis", "congenital self-healing Langerhans cell histiocytosis" and "Hashimoto-Pritzker disease".

\section{Case presentation}

A male full term neonate, born spontaneously after an uncomplicated pregnancy from non-consanguineous parents, presented at birth multiple polymorphic cutaneous manifestations on the trunk, limbs, and head: vesicles, blisters, pustules, erythematous and exudative lesions (Fig. 1A). In addition, small erosions were present on the tongue (Fig. 1B). The baby was otherwise healthy, with appropriate gestational age (AGA), regular cardiovascular adaptation, normal tone and neonatal reflexes. He was afebrile with stable vital signs and the

C C The Author(s). 2021 Open Access This article is licensed under a Creative Commons Attribution 4.0 International License, which permits use, sharing, adaptation, distribution and reproduction in any medium or format, as long as you give appropriate credit to the original author(s) and the source, provide a link to the Creative Commons licence, and indicate if changes were made. The images or other third party material in this article are included in the article's Creative Commons licence, unless indicated otherwise in a credit line to the material. If material is not included in the article's Creative Commons licence and your intended use is not permitted by statutory regulation or exceeds the permitted use, you will need to obtain permission directly from the copyright holder. To view a copy of this licence, visit http://creativecommons.org/licenses/by/4.0/. The Creative Commons Public Domain Dedication waiver (http://creativecommons.org/publicdomain/zero/1.0/) applies to the data made available in this article, unless otherwise stated in a credit line to the data. 

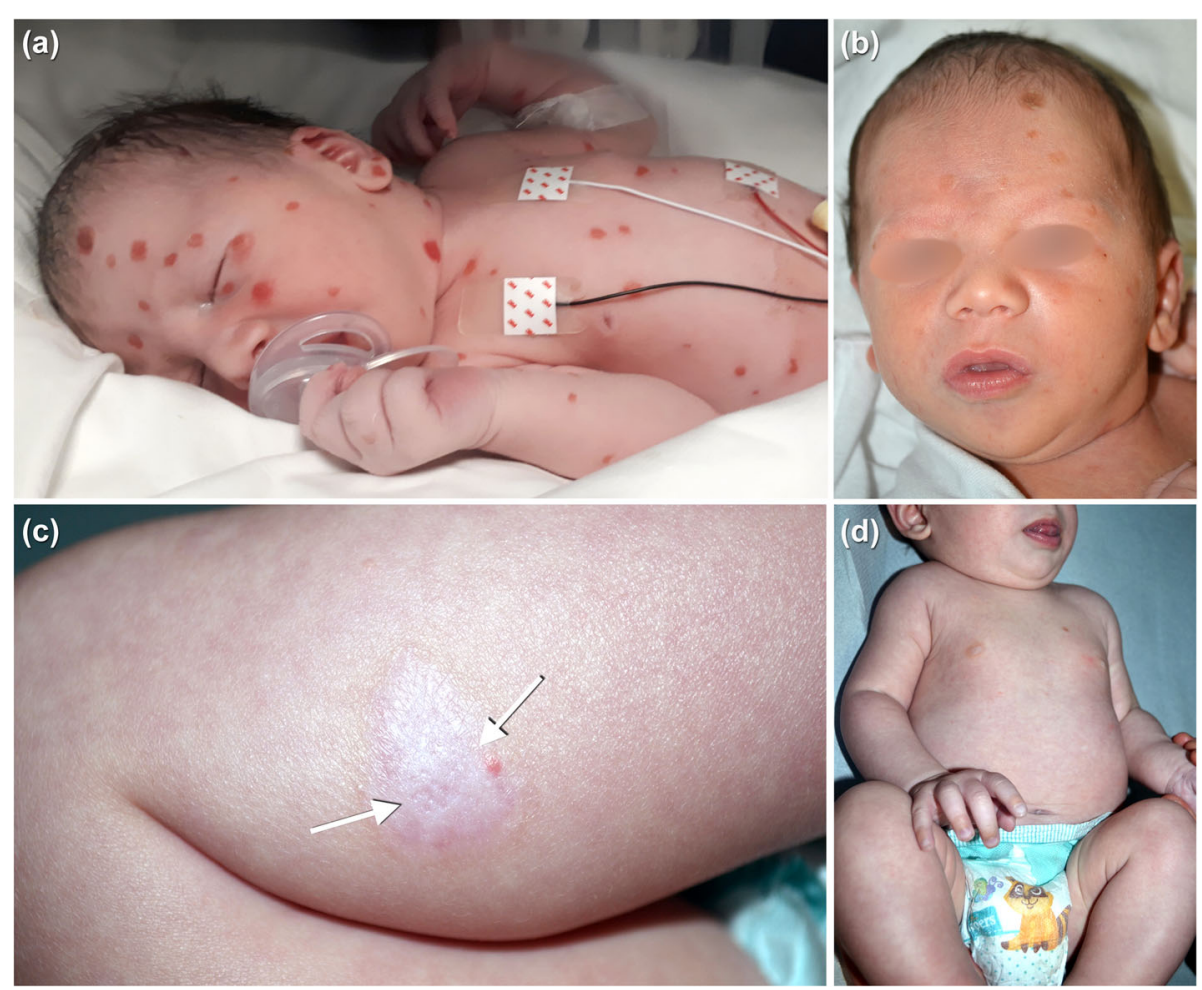

Fig. 1 Clinical features of the patient. Round shaped erosions diffuse on the body $(\mathbf{A})$; small erosion on the right side of the of the tongue (B); hypopigmented and slightly atrophic scar on the right lower leg (C); complete healing of the lesions at 5 months of age(D)

remainder of his physical examination was normal; no lymphadenopathy or organomegaly was noted. No family history for blistering diseases.

Congenital infections were ruled out through bacterial cultures and maternal serology for TORCH complex (Toxoplasma, Rubella, Citomegalovirus, Herpes virus, syphilis, varicella-zoster, parvovirus B19,). Patient's serology for TORCH group infections, Epstein-Barr virus, Coxsackie virus $\mathrm{A}$ and $\mathrm{B}$ and Adenovirus was negative. Complete blood-cell count, kidney and liver function tests, clotting tests, and C-reactive protein were normal. Polymerase chain reaction for Herpes Simplex Virus 1/2, Human Herpes Virus 6 and Coxsackie virus on vesicular content was negative.

The mother was tested for anti-SSA and anti-SSB, and neonatal lupus was excluded.

On the fifth day of life, the baby was discharged in good general conditions and referred to Dermatology Unit at Bambino Gesù Children's Hospital for further investigation. The patient manifested atrophic and dyschromic scars on the trunk, face and limbs; small vesicles and erythematous papules were present on the face and scalp (Fig. 1C).

A skin biopsy was performed. Histopathological examination showed a dense infiltrate of large histiocytic cells, with pale cytoplasm and reniform nucleus, filling the papillary dermis and infiltrating the epidermis (Fig. 2A). The histiocytes stained positive for CD1a (Fig. 2B), Langherin (CD207), S100 protein and e-cadherin. BRAF V600E mutation has been identified both with immunohistochemistry and polymerase chain reaction (PCR).

The baby was then evaluated together with a pediatric oncohematologist to perform a complete disease staging with imaging and laboratory studies.

Complete blood count, coagulation studies, serum urea, creatinine, bilirubin, liver enzymes and thyroid function tests were within normal limits. Abdominal ultrasound, whole body MRI and brain MRI seemed unremarkable.

A presumptive diagnosis of self-healing histiocytosis Hashimoto-Pritzker was established, due to almost complete resolution of the mucocutaneous lesions and absence of extracutaneous involvement. Topical mometasone fuorate ointment was initiated and a follow-up was planned.

At 2 months of age, all lesions disappeared, with some residual scars. At 5 months follow-up the patient is healthy (Fig. 1D).

\section{Discussion and conclusions}

$\mathrm{LCH}$ is a rare clonal disease of the monocytemacrophage system characterized by uncontrolled proliferation and accumulation of $\mathrm{CD} 1 \mathrm{a}^{+} / \mathrm{CD} 207^{+}$dendritic 

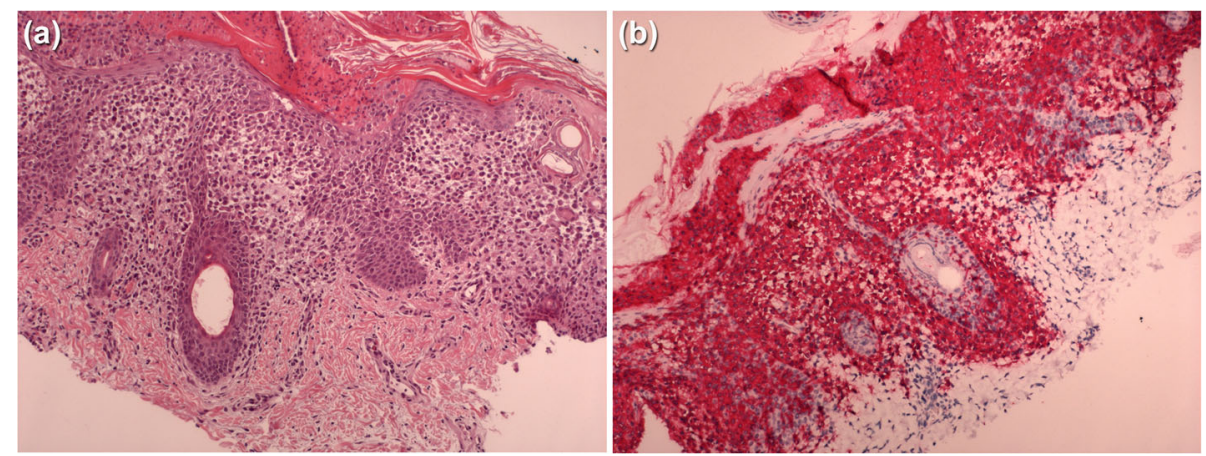

Fig. 2 Skin biopsy shows dermal infiltrate with epidermotropism (E\&E 10X) (A); CD1a immunostain displays positive Langherans cells (IHC 10X) (B)

cells [7]. The clinical behavior of LCH is remarkably heterogeneous and may range from isolated, self-healing skin and bone lesions to life-threatening multi-system condition.

Generally, patients with $\mathrm{LCH}$ can be divided into two groups based on the extent of involvement at diagnosis, namely, single-system $\mathrm{LCH}$ and multisystem $\mathrm{LCH}$. The single-organ involvement may be unifocal or multifocal. Specific organs are considered high risk; they include the liver, spleen and hematopoietic system. Approximately $65 \%$ of patients have single-system disease [8]. Bone is the most common single-organ site (80\% of cases) followed by the skin (12\%) [9].

Congenital self-healing reticulohistiocytosis (CSHRH) is characterized by absence of systemic symptoms and spontaneous involution. In addition, dermatological manifestations are peculiar compared to the other $\mathrm{LCH}$ types. More than 100 cases have been reported in literature. This disease is probably underestimated due to the lack of extracutaneous involvement and spontaneous resolution within few weeks or months.

The most common presentation is characterized by diffuse multiple erythematous to purpuric-brown papulonodules or vesicles on the skin. In addition, cutaneous blisters and mucous erosions are very rarely reported. Indeed, although some authors have emphasized the absence of mucous membrane involvement, oral lesions have been described in five patients within the first days of disease manifestation [4, 10, 11]. Our patient presented since birth cutaneous blisters and few erosions in the oral mucosa without feeding difficulties [12]. Isolated lesions have been reported approximately in $25 \%$ of cases without preferred site; the disease onset is usually at birth, and in some cases within early childhood [13]. Few patients with CSHRH manifested at birth numerous blue-purplish and dark-red papular, nodular lesions; this presentation is considered part of the spectrum of blueberry muffin baby (BMB) [3]. Other rare and atypical cutaneous manifestations in children with $\mathrm{CSHRH}$ are diffuse hypopigmented flat-topped papules [14].
Differential diagnoses of CSHRH should consider: congenital or acquired infections (syphilis, impetigo, herpes, staphylococcal scaled-skin syndrome, etc.), autoimmune diseases (neonatal pemphigus or neonatal lupus erythematosus) or other haematological disorders [12].

Upon literature review, the most frequent sequela of CSHRH is post-inflammatory hyper- or hypopigmentation. Residual scars, milia, and anetoderma, especially in larger lesions are also reported [15]. Indeed, our patient presented dyschromic and atrophic scars on the trunk and right leg (Fig. 1C).

The diagnosis of LCH is based on histopathology and immunohistochemistry, which are the same in all forms of $\mathrm{LCH}$. The hallmark cells stain positive for $\mathrm{S} 100$ protein, CD1a and Langherin (CD207), a monoclonal antibody direct against a type II transmembrane c-type lectin protein of Birbeck granules [16]. The activating BRAFV600E mutation has been recently identified as a frequent molecular genetic alteration both in systemic $\mathrm{LCH}$ and in CSHRH. The presence of circulating cells carrying the mutation is considered predictive of disseminate disease [17]. In our patient BRAFV600E mutation was present only on Langerhans cells of the skin.

The diagnosis of CSHRH is confirmed through clinical features, absence of extracutaneous involvement, early spontaneous healing, and histology. Moreover, relapse of cutaneous manifestation and/or subsequent visceral involvement including lungs, eyes, or bones have been described, especially in the first year of life. These data suggested that a long-term follow-up is mandatory $[3,5,6,18-20]$.

No specific treatment for congenital self-healing reticulohistiocytosis is required, apart from topical management for blisters and erosions as in our patient, or systemic antibiotics in case of bacterial superinfection [18].

In conclusion, our case confirms that congenital lesions of oral mucosa in CSHRH are possible. In our opinion this localization is probably underestimated due to fugacity of the erosions and difficulties in exploring the oral cavity in a newborn with normal feeding. 
Patients affected with $\mathrm{LCH}$, without extracutaneous involvement who manifest a benign course require a follow-up until the first year of life because the diagnosis of CSHRH can be confirmed only a posteriori.

\section{Abbreviations}

CSHRH: Congenital self-healing reticulohistiocytosis; LCH: Langerhans cell histiocytosis; AGA: Appropriate gestational age; TORCH complex: (Toxoplasma, Rubella, Citomegalovirus, Herpes virus, syphilis, varicella-zoster, parvovirus B19,); BMB: Blueberry muffin baby

\section{Acknowledgements}

None.

\section{Authors' contributions}

All authors contributed, read and approved the final manuscript.

\section{Funding}

Not applicable.

\section{Availability of data and materials}

Data are recorded in our intranet.

\section{Declarations}

Ethics approval and consent to participate Not applicable.

\section{Consent for publication}

Parents gave their informed consent for publication of the manuscript and pictures.

\section{Competing interests}

The authors declare that they have no competing interests.

\section{Author details}

'Neonatal Intensive Unit, San Pietro - Fatebenefratelli Hospital, Rome, Italy. ${ }^{2}$ Dermatology Unit, Bambino Gesù Children's Hospital, IRCCS, Piazza S. Onofrio, 4, 00165 Rome, Italy. ${ }^{3}$ Pathology Unit, Bambino Gesù Children's Hospital, IRCCS, Rome, Italy. ${ }^{4}$ Department of Hematology-Oncology and Cellular and Gene Therapy, Bambino Gesù Children's Hospital, IRCCS, Rome, Italy

Received: 26 May 2020 Accepted: 20 May 2021

Published online: 10 June 2021

\section{References}

1. Hashimoto K, Pritzker MS. Electron microscopic study of reticulohistiocytoma. An unusual case of congenital, self-healing reticulohistiocytosis. Arch Dermatol. 1973;107(2):263-70. https://doi.org/10.1 001/archderm.1973.01620170071020.

2. Hashimoto K, Bale GF, Hawkins HK, Langston C, Pritzker MS. Congenital selfhealing reticulohistiocytosis (Hashimoto-Pritzker type). Int J Dermatol. 1986; 25(8):516-23. https://doi.org/10.1111/j.1365-4362.1986.tb00867.x

3. Hansel K, Tramontana M, Troiani S, de Benedictis D, Bianchi L, Cucchia R, et al. Congenital self-healing Langerhans cell Histiocytosis: a rare presentation of blueberry muffin baby "Spectrum". Dermatopathology. 2019; 6(2):37-40. https://doi.org/10.1159/000499311.

4. Larralde M, Rositto A, Giardelli M, Gatti CF, Santos MA. Congenital selfhealing histiocytosis (Hashimoto-Pritzker). Int J Dermatol. 1999;38(9):693-6. https://doi.org/10.1046/j.1365-4362.1999.00758.x.

5. Lee YH, Talekar MK, Chung CG, Bell MD, Zaenglein AL. Congenital selfhealing reticulohistiocytosis. J Clin Aesthet Dermatol. 2014;7(2):49-53.

6. Mandel VD, Ferrari C, Cesinaro AM, Pellacani G, Del Forno C. Congenital "self-healing" Langerhans cell histiocytosis (Hashimoto-Pritzker disease): a report of two cases with the same cutaneous manifestations but different clinical course. J Dermatol. 2014;41(12):1098-101. https://doi.org/1 $0.1111 / 1346-8138.12670$

7. Emile JF, Abla O, Fraitag S, Horne A, Haroche J, Donadieu J, et al. Revised classification of histiocytoses and neoplasms of the macrophage-dendritic cell lineages. Blood. 2016;127(22):2672-81. https://doi.org/10.1182/blood-201 6-01-690636.

8. Morimoto A, Ishida Y, Suzuki N, Ohga S, Shioda Y, Okimoto Y, et al. Nationwide survey of single-system single site Langerhans histiocytosis in Japan. Pediatr Blood Cancer. 2010;54(1):98-102. https://doi.org/10.1002/ pbc.22224.

9. Thacker NH, Abla O. Pediatric Langerhans cell histiocytosis: state of the science and future directions. Clin Adv Hematol Oncol. 2019;17(2):122-31.

10. Herman LE, Rothman KF, Harawi S, Gonzalez-Serva A. Congenital selfhealing reticulohistiocytosis. A new entity in the differential diagnosis of neonatal papulovesicular eruptions. Arch Dermatol. 1990;126(2):210-2. https://doi.org/10.1001/archderm.1990.01670260080016.

11. Longaker MA, Frieden IJ, LeBoit PE, Sherertz EF. Congenital "self-healing" Langerhans cell histiocytosis: the need for long-term follow-up. J Am Acad Dermatol. 1994:31(5):910-6. https://doi.org/10.1016/50190-9622(94)70258-6.

12. Le Bidre $\mathrm{E}$, Lorette $\mathrm{G}$, Delage $\mathrm{M}$, et al. Extensive, erosive congenital selfhealing cell histiocytosis. J Eur Acad Dermatol Venereol. 2009;23(7):835-6. https://doi.org/10.1111/j.1468-3083.2008.03023.x.

13. Weiss T, Weber L, Scharffetter-Kochanek K, Weiss JM. Solitary cutaneous dendritic cell tumor in a child: role of dendritic cell markers for the diagnosis of skin Langerhans cell histiocytosis. J Am Acad Dermatol. 2005; 53(5):838-44. https://doi.org/10.1016/j.jaad.2005.07.011.

14. Uaratanawong R, Kootiratrakarn $T$, Sudtikoonaseth P, Issara A, Kattipathanapong P. Congenital self-healing reticulohistiocytosis presented with multiple hypopigmented flat-topped papules: a case report and review of literatures. J Med Assoc Thail. 2014;97(9):993-7.

15. Larsen L, Merin MR, Konia T, Armstrong AW. Congenital self-healing reticulohistiocytosis: concern for a poor prognosis. Dermatol Online J. 2012; 18:2.

16. Lau SK, Chu PG, Weiss LM. Immunohistochemical expression of Langerin in Langerhans cell histiocytosis and non-Langerhans cell histiocytic disorders. Am J Surg Pathol. 2008;32(4):615-9. https://doi.org/10.1097/PAS.0b013e3181 $5 b 212 b$

17. Simko SJ, Garmezy B, Abhyankar H, Lupo PJ, Chakraborty R, Lim KPH, et al. Differentiating skin-limited and multisystem Langerhans cell histiocytosis. J Pediatr. 2014;165(5):990-6. https://doi.org/10.1016/j.jpeds.2014.07.063.

18. Orle J, Mósca AM, Sousa MA, Lima CM, Adriano AR, Rezende PM. Congenital self healing reticulohistiocytosis in a newborn (Hashimoto Pritzker). An Bras Dermatol. 2011;86(4):785-8. https://doi.org/10.1590/50365-059620110004 00026.

19. Yu J, Rubin Al, Castelo-Soccio L, Perman MJ. Congenital self-healing Langerhans cell Histiocytosis. J Pediatr. 2017;184:232. https://doi.org/10.101 6/j.jpeds.2017.01.040

20. Goo HW, Yang DH, Ra YS, Song JS, Im HJ, Seo JJ, et al. Whole-body MRI of Langerhans cell histiocytosis: comparison with radiography and bone scintigraphy. Pediatr Radiol. 2006:36(10):1019-31. https://doi.org/10.1007/ s00247-006-0246-7.

\section{Publisher's Note}

Springer Nature remains neutral with regard to jurisdictional claims in published maps and institutional affiliations.

Ready to submit your research? Choose BMC and benefit from:

- fast, convenient online submission

- thorough peer review by experienced researchers in your field

- rapid publication on acceptance

- support for research data, including large and complex data types

- gold Open Access which fosters wider collaboration and increased citations

- maximum visibility for your research: over $100 \mathrm{M}$ website views per year

At BMC, research is always in progress.

Learn more biomedcentral.com/submissions 